\title{
CONFESSIONAL ATTACHMENT AND ELECTORAL BEHAVIOR IN THE NETHERLANDS*
}

\author{
WARREN E. MILLER \\ University of Michigan, Ann Arbor, U.S.A. \\ and \\ PHILIP C. STOUTHARD \\ Katholieke Hogeschool, Tilburg, The Netherlands
}

\begin{abstract}
The analysis presented in this paper seeks to outline some of the political consequences of a general decline in the place of the church and religious faith in peoples' daily lives in the Netherlands. It juxtaposes a reconstruction of religious origins or backgrounds against current assessment of the strength of confessional attachments. Erosion of traditional ties to the church of one's early loyalties is depicted as accompanied by withdrawal from formal participation in the electoral process. Interest in politics and informal participation remain high, but the rejection of institutionalized religion is associated with what appears to be an active rejection of institutionalized politics. For those who do remain in the active electorate, a continued decline in confessional attachment appears to forecast a continued decline in confessional party vote.

Insofar as change in the future involves general depillarization, or decreased political relevance of the church for all degrees of confessional attachment, the political beneficiaries may be the parties of center and right as well as left. An across-the-board drop in level of confessional voting would mean that many voters with strong confessional attachments would be turning to the secular parties and in doing so - if the recent past is any guide - would turn no more often to the left than to the other options open to them. However, insofar as the future brings a decline in confessional attachment without a diminution in the relevance of confes-

\footnotetext{
* This article is based on two national sample surveys, conducted in 1970 and 1972 as part of a program of political research carried out in a partnership of the Katholieke Hogeschool, Tilburg, and Leiden University, The Netherlands, and the University of Michigan, U.S.A. Support was given by all three institutions, The Netherlands Organization for the Advancement of Pure Research (Z.W.O.) the Ford Foundation and the National Science Foundation through their grant GS-36401. In addition to the authors of this article, Professors Hans Daalder, Leiden University, and M. Kent Jennings and Jerrold Rusk of the University of Michigan made major contributions to the research program.
} 
sional attachment for confessional voters, the parties of the left will benefit disproportionately as the newly deconfessionalized turn away from the parties of tradition and seek out the parties of change.

The pervasiveness of on-going change in the religious communities of the Netherlands provides an opportunity to examine how changes in one set of institutions lead to changes in another. The discussion that follows is motivated by a primary interest in the political consequences of the decreasing strength of the religious pillars on which so much of Dutch society has rested.

The intersection of social cleavages and political alignments provides an important focus for the analysis of political behavior. It is of particular interest in the Netherlands because both the society and its politics are in transition. The country is moving away from a set of arrangements that had been traditionally based on an unusually close congruence between major social cleavages and political alignments. Indeed, the particular manner in which a small national community reconciled social segmentation based on sharp differences of class and religious outlook with the spirit and machinery of democratic government has commanded the attention of many observers and scholars. In recent years, however, it has become apparent that the old formulae of accommodation that created a consociational polity have been placed under heavy strain by the many changes taking place in the country. The well-publicized upheavals within the Catholic Church, the increased fragmentation of the party system and the many manifestations of broadened commitment to new forms of social and political participation are among the more notable indicators of such changes. Although the Netherlands has seldom been portrayed as a "typical" western (or even typical European) polity, the traditional alignments of Dutch social and political cleavages have been characteristic of many continental European countries. And although social change in Dutch society may have its national peculiarities, the ferment that is associated with political change in The Netherlands does not seem to be totally atypical of change elsewhere. Even without overt attention to comparisons and similarities with other countries, it is hoped that a part of the usefulness of this discussion will be found in the more or less ubiquitous nature of the phenomena being discussed. ${ }^{1}$

\section{The Measurement of Confessional Attachment and Deconfessionalization}

Our inquiry begins with an assessment of current attachment or com- 
TABLE I

1970 Distribution of Confessional Attachment, Total Population

\begin{tabular}{|c|c|}
\hline Have a religious preference, and & $\%$ \\
\hline Always attend church* & 29 \\
\hline Usually attend church & 13 \\
\hline Sometimes attend church & 11 \\
\hline Seldom attend church & 8 \\
\hline \multicolumn{2}{|l|}{ Have a religious preference but } \\
\hline Never attend church & 11 \\
\hline \multirow[t]{2}{*}{ Have no religious preference } & 28 \\
\hline & 100 \\
\hline Number of Respondents & $(1821)^{* *}$ \\
\hline
\end{tabular}

mitment to the major religious institutions of Dutch society. Our data resources provide an essentially behavioral indicator, frequency of church attendance. Information on religious preference, or identity, and church attendance make possible the following assessment of confessional attachment among Dutch adults in the spring of 1970.

This current description of confessional attachment has points both of similarity and of contrast with earlier times. On the one hand, if somewhat more than half of the adults represent themselves as more or less faithful religious participants today, almost $50 \%$ of the adults in The Netherlands (although not the same 50\%) come from homogeneous religious backgrounds where both parents were of the same religion and where they themselves attended a confessional school of that religion. At the other extreme, persons who have no current religious preference or identity and whose parents were nonreligious constitute only about $7 \%$ of the total population, whereas more than a quarter of the current population professes no religion today. Those who are in the second generation without a stated religious preference are not only quite distinctive in their own right but they are also useful as a base for subsequent comparison with the much larger group who apparently have rejected their religious heritage despite a homogeneous background in one faith or the other.

Ideally, we would like to be able to depict the various shifts that have led to the current set of attachments. With data that would indicate both when and in what ways change had occurred, we could identify periods when, for example, strong attachments were weakened or 
weak attachments replaced with conversion or with a rejection of religion. Our information sources do not permit such a detailed reconstruction. Instead, we have, and then by inference, information on confessional attachment at only one earlier point in time, the period of putative religious socialization. For each person we have four pieces of information with which to reconstruct his or her religious background: 1) report of mother's religion, 2) report of father's religion, 3) report of own attendance at a confessional rather than a public school, and 4) identification of the religious affiliation of such a confessional school. With this information, and the current statement of confessional attachment, it is possible to fashion an approximate description of the extent of "deconfessionalization" in the current population by contrasting the current assessment of confessional attachment with the reconstruction of the earlier point in time.

Our interest in deconfessionalization, and in clarifying the meaning of current statements of confessional attachment, dictated a particular use of our information about the current population of adults and their parents. Rather than try to work with all of the complexities which even the few pieces of available information could generate, we turned to a set of simplifying decisions that would produce four major groups for analytic comparison. First, in addition to the group of second generation nonreligious, other groups with homogeneous religious backgrounds were defined as constituted when 1) both parents were of the same religion or when 2) a person had attended a confessional school of the faith held by at least one parent. ${ }^{2}$

From each religious group so defined, we then deleted all cases in which a person's current religious preference was other than the religion into which he or she was presumably socialized. All converts, from one religion to another or from a nonreligious background to some confessional attachment, are therefore excluded from our analysis. However, persons from a homogeneous religious background but with no current religious preference are retained within their respective grouping. Finally, all minor religions (represented by unreliably small numbers of cases on our data base) were set aside. These decisions produced four groupings for subsequent analysis: 1) a homogeneous Catholic group making up $40 \%$ of the total population, 2) a homogeneous Dutch Reformed group constituting $26 \%$ of the total, 3 ) a homogeneous Calvinist group made up of $9 \%$ of all adults, and 4) the nonreligious group composed of $7 \%$ of the adult population. ${ }^{3}$

Some $18 \%$ of the adults in the Netherlands are excluded from our analysis. In some instances the exclusion occurs despite a potential interest in such phenomena as religious conversion (perhaps $4 \%$ of the 
total) or the consequences of mixed marriage ( $2 \%$ report one Catholic parent and one Protestant). The bulk of the 18\%, however, is made up from a variety of cases in which it is not possible to establish that a person's current stance toward religion represents a departure from childhood experience in home and school and is therefore a possible indication of deconfessionalization. The footnote in Table II describes these cases in somewhat greater detail.

Using our definition of homogeneity in religious background, a rather global description of the current state of change in confessional attachment in Dutch society is presented in Table II. That table pre-

\section{TABLE II}

Confessional Attachments in Dutch Society in 1970, for Major Groups with Homogeneous Religious Background

\begin{tabular}{|c|c|c|c|c|c|c|c|}
\hline \multirow[b]{2}{*}{ Current Attachment } & \multicolumn{5}{|c|}{ Religious Background } & \multirow{2}{*}{\multicolumn{2}{|c|}{$\begin{array}{c}\text { Total } \\
\text { Cases Percent }\end{array}$}} \\
\hline & $\begin{array}{l}\text { Catholic } \\
\text { (K) }\end{array}$ & $\begin{array}{l}\text { Dutch } \\
\text { Reformed } \\
\text { (DR) }\end{array}$ & $\begin{array}{l}\text { Calvinist } \\
\text { (C) }\end{array}$ & $\begin{array}{l}\text { Non- } \\
\text { Religious } \\
\text { (NR) }\end{array}$ & Other & & \\
\hline Attend Church & $\begin{array}{c}31 \\
(576)^{* *}\end{array}$ & $\begin{array}{c}14 \\
(255)\end{array}$ & $\begin{array}{c}7 \\
(135)\end{array}$ & 0 & - & $(966)$ & $53^{*}$ \\
\hline $\begin{array}{l}\text { Identify with religion } \\
\text { of origin but do not } \\
\text { attend church }\end{array}$ & $\begin{array}{c}3 \\
(63)\end{array}$ & $\begin{array}{c}5 \\
(90)\end{array}$ & $\begin{array}{l}* \\
(5)\end{array}$ & 0 & - & $(158)$ & $9 *$ \\
\hline $\begin{array}{l}\text { Have no religious } \\
\text { preference }\end{array}$ & $\begin{array}{c}5 \\
(96)\end{array}$ & $\begin{array}{c}7 \\
(120)\end{array}$ & $\begin{array}{c}1 \\
(24)\end{array}$ & $\begin{array}{c}7 \\
(132)\end{array}$ & - & $(372)$ & 20 \\
\hline Other & $40 \% *$ & - & - & $7 \%$ & $\begin{array}{l}18 \\
, \quad 18 \% * * *\end{array}$ & ${ }_{*}^{(338)}$ & $\begin{array}{r}18 \\
100\end{array}$ \\
\hline $\begin{array}{l}\text { Number of Respon- } \\
\text { dents }\end{array}$ & $(735)$ & $(465)$ & $(164)$ & $(132)$ & $(338)$ & 1834 & \\
\hline
\end{tabular}

* Entries of these columns and rows do not add to column and row totals because of fractions less than 0.5 being distributed among two or more categoties.

** Figures in parentheses indicate number of cases.

*** Includes 136 cases ( $7 \%$ of total) where the respondent has no current religious preference but respondent's religious origin was in some religion other than $K, D R$ and $C$, where the religious origin is mixed, or where the religious origin is unclear; 68 cases (4\% of total) where respondent's origins are clearly $\mathrm{K}, \mathrm{DR}$ or $\mathrm{C}$ and where the respondent has converted to another religion; and 134 cases ( $7 \%$ of total) where the religion is a minor religion in the Netherlands (Jews, Lutherans, Remonstrants, etc.), where the religion of origin is unclear (mixed marriages and no church school attendance) or where missing data for parents or respondent makes classification impossible. 
sents the current expressions of confessional attachment within each of the four groups with homogeneous religious backgrounds. A close comparison with Table I leads to the correct inference that the incidence of religious preference or church attendance among the $18 \%$ in the residual "other" category is lower than for the major segments of the population that will concern us in the remainder of this discussion. Consequently, insofar as those in the residual group with little or no confessional attachment are like the "deconfessionalized" in our major groups, the impact of the absence of confessional attachment on Dutch politics may be understated in our subsequent analysis.

Comparisons across the three religious groupings (among the four) are facilitated by a more detailed inspection of contemporary church attendance. As demonstrated in Table III, a contrast between Dutch Reformed and Calvinist is immediately apparent, with the latter showing a remarkable degree of behavioral adherence to family traditions and, therefore, limited evidence of probable deconfessionalization. Five out of every six persons ( $83 \%$ ) of Calvinistic background report attending church at least occasionally, while nearly half $(45 \%)$ of the Dutch Reformed group reports either nonattendance or the absence of any religious preference at all. However, the very extremity of this contrast provides an occasion to warn against the assumption that we are necessarily observing only the consequences of deconfessionalization. There is every reason to expect that some part of the difference between the two Protestant groups is one of the persistent differences in emphasis placed on adherence to group norms among those of the fundamentalist religions and members of the latitudinarian sects. We may be reasonably

TABLE III

Confessional Attachment of Major Groups Defined by Religious Background, 1970

\begin{tabular}{|c|c|c|c|c|c|c|c|c|}
\hline \multirow[b]{3}{*}{ Attend Church: Always } & \multirow[b]{3}{*}{$51 \%$} & \multirow{3}{*}{$\begin{array}{l}\mathrm{K} \\
44 \%\end{array}$} & \multirow{2}{*}{\multicolumn{2}{|c|}{ DR }} & \multirow{2}{*}{\multicolumn{2}{|c|}{$\mathrm{C}$}} & \multicolumn{2}{|c|}{ Total } \\
\hline & & & & & & & Cases & Percent \\
\hline & & & $22 \%$ & $17 \%$ & $61 \%$ & $53 \%$ & $(487)$ & 35 \\
\hline Usually & 19 & 16 & 14 & 10 & 25 & 22 & $(204)$ & 15 \\
\hline Sometimes & 13 & 11 & 18 & 13 & 9 & 8 & $(155)$ & 11 \\
\hline Seldom & 7 & 7 & 20 & 15 & 1 & $*$ & $(120)$ & 9 \\
\hline Never & 10 & 8 & 26 & 20 & 4 & 3 & $(158)$ & 12 \\
\hline & 100 & & 100 & & 100 & & & \\
\hline \multirow[t]{2}{*}{ No religious preference } & & 13 & & 25 & & 14 & $(240)$ & 18 \\
\hline & & 100 & & 100 & & 100 & & 100 \\
\hline Number of Respondents & & $(735)$ & & $(465)$ & & (164) & & (1364) \\
\hline
\end{tabular}


comfortable in assuming that almost all of the departures from earlier acceptance of religious norms are embedded or reflected in the distributions of limited confessional attachment. However, we cannot assume that the report of religious homogeneity in home and school indicates a completely uniform degree of religious socialization and, therefore, an unambiguous base for the measurements of initial attachments. Consequently, we cannot assume that all subsequent reports of nonattendance or nonidentification within the three religious groups must reflect change during the adult lifetime of the person reporting. ${ }^{4}$

\section{Confessional Voting in 1970}

Religious group differences in gross voting patterns in the 1970 provincial elections, as presented in Table IV, are thoroughly familiar to students of recent Dutch politics. The Calvinist vote was heavily confessional (Anti-Revolutionary Party or ARP), the nonreligious vote even more strongly secular, the Catholic vote predominantly confessional (Catholic People's Party or KVP) and the Dutch Reformed vote almost as secular as the Catholic vote was confessional. Data from 1966 originally reported in God in Nederland by Zeegers et al., (1967) provide a base that suggests that 1970 saw a continuation of depillarization of the Catholic vote, while the votes of our other three groups apparently

\section{TABLE IV}

1970 Provincial Election Vote, by Religious Background

\begin{tabular}{lcccc}
\hline & K & DR & C & NR \\
\hline Confessional* & $34 \%$ & $23 \%$ & $62 \%$ & $2 \%$ \\
Other & 35 & 53 & 28 & 69 \\
Non Vote & 29 & 19 & 10 & 23 \\
Refused to Answer, DK, NA & 2 & 5 & $\overline{6}$ & $\frac{6}{100}$ \\
& 100 & $\overline{100}$ & 100 & $(132)$ \\
Number of Respondents & $(735)$ & $(465)$ & $(164)$ & \\
\hline
\end{tabular}

1 out of $507 \mathrm{~K}$ voted ARP or CHU

3 out of 364 DR voted KVP

0 out of $142 \mathrm{C}$ voted KVP or CHU

$\underline{2}$ out of 102 NR voted KVP, ARP or CHU

6 out of 1115 voters crossed religious lines

* The Confessional Parties represented in the table include: KVP, Katholieke 'Volkspartij; ARP, Anti-Revolutionaire Partij; CHU, Christelijk Historische Unie, SGP, Staatkundig Gereformeerde Partij; and GPV, Gereformeerd Politiek Verbond. 
remained stable in their divison between the confessional and the secular parties. A still earlier base provided by the Lijphart (1974) and Wolinetz (1973) reanalyses of 1956 data provides perhaps the clearest evidence that depillarization (declining strength of church-related organizations including the confessional parties) has taken place in Dutch politics, whether or not there has also been deconfessionalization (declining individual religious attachment) of a comparable magnitude. In 1956 , voters among the Catholics and Calvinists were apparently almost monolithic in their support of the appropriate confessional parties. By 1970 the Catholic vote for the KVP had dropped from the $84 \%$ of all Catholics as recorded in 1956 to only 59\%; the Calvinist vote was down from $80 \%$ voting ARP to barely $70 \%$ in 1970 . Even the Dutch Reformed support for their confessional parties (Christian Historical Union and ARP) showed a comparable proportional drop from $39 \%$ in 1956 to $23 \%$ in 1970 , a decline of $40 \%$ in votes cast for confessional parties to more than match the $35 \%$ decrease in Catholic votes for the KVP and the $13 \%$ decline in Calvinist ARP voting.

Whatever the magnitude of deconfessionalization or depillarization between the mid-1950s and the early 1970s, one aspect of segmental division along religious lines did not change. Although only $34 \%$ of the Catholic group being studied in 1970 reported voting and voting KVP, only one Catholic out of the total 507 who reported voting, voted for any other confessional party - one vote for the CHU. More than half of the Dutch Reformed voted for some party other than CHU or ARP, but only 3 out of 364 Dutch Reformed voters voted KVP. Not one of the 142 Calvinist voters admitted to a KVP or CHU vote in 1970, and only 2 out of 102 nonreligious voters voted for any confessional party. In sum, only 6 out of 1115 voters crossed traditional confessional lines in their 1970 vote. The pillars that once supported the religious parties may be crumbling but the historic boundaries separating them remain as inviolate as ever. Catholics and Protestants alike may share a growing sense that political salvation may be found outside their own confessional communities, but the freedom to go outside one's own religious community is not matched by freedom to enter another. As we shall note shortly, the same strictures held in 1972, with the inevitable consequence that the confessional parties as a group again lost popular support in that year.

\section{Perspectives on Change in Confessional Voting}

The unidirectional flow of voters away from the confessional parties 
forces attention in two directions: looking back to the source of the problem, how does one account for and understand the decline of confessional party strength? Looking forward, what are the likely consequences of a continuation of the massive desertions that have brought the confessional vote down from its post-war high of 53\% in 1948 to only $32 \%$ in 1972 ? In the most general terms, the origin of the decline might be found in any of three, nonexclusive, types of change. First, with no change in the level of confessional attachment within any of the major religious groupings, a diminution of the bond between religion and politics could account for the precipitous decline in confessional voting. Second, with no change in the correlation between confessional attachment and confessional voting, confessional voting could decline just because confessional attachment itself has declined. In the third case, both level of confessional attachment and level of confessional voting could change, with no change in their relationship.

Just as the status polarization of political partisanship may surge and ebb with shifts in the congruence of political and class alignments, so too the correlation between confessional attachment and confessional voting may grow and decline with no change occurring either in the general level of politicization or in the level of confessional attachment (see Campbell et al., 1960, pp. 333-377). Accounting for a decline in confessional voting through a reduction in the religious relevance of politics, expressed as a reduction in the correlation between confessional attachment and confessional voting, would, of course, mean differential change occurring along the dimension of confessional attachment. A decline in the strength of the relationship between religion and politics in the presence of a decline in confessional voting would necessarily mean a greater decline or reduction in confessional voting for those with the higher levels of confessional attachment. This would be accompanied by a smaller decline for the less attached who, presumably, are less united in confessional voting to begin with precisely because they feel less attached to the church of their choice and less obligated to vote the party line. This pattern of change $\left(t_{1}\right.$ to $t_{2}$ in Chart A) would seem to promise still more change to come, because it would mean an erosion of norms set and exemplified by the most faithful within the religious community. If those closest to the church decrease their commitment to the church's party, the less faithful may well feel an increased freedom to follow personal dictates of political interest, or disinterest, on election day.

As a second stage in the dynamics of this type of change within a group, a decision of the more peripheral members of the group to desert the group's party could, somewhat paradoxically, restore the 


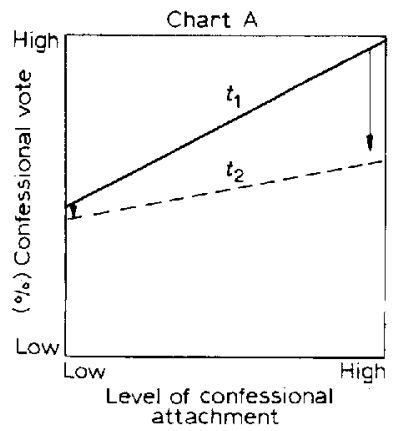

original correlation between the confessional attachment and voting but at the continued overall expense of the confessional party. At the end of this stage in the evolution of church-party relationship ( $t_{3}$ in Chart B), the more committed members of the religious community would

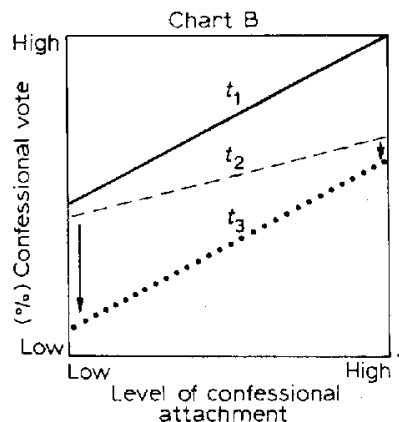

once again be relatively more faithful supporters of the church's party than those with lower levels of confessional attachment, but all would share in a lower level of support for the party. Whatever the starting point in the process, persons at every point on the gradient of confessional attachment would, at the end of this process, give less weight to confessional concerns and more weight to other factors in coming to their decision to vote. And during such a process of political depillarization, the correlations between confessional attachment and confessional voting could be expected to first drop and then rise if those most committed were the first to change and the least committed followed their example.

An initial increase in the confessional attachment-confessional vote correlation could occur at the beginning of a period of decline in confessional voting, but it would mean that the process of change within the group was beginning with defection or rebellion at the periphery, among those least attached (as in $t_{1}$ to $t_{2}$. in Chart $\mathrm{C}$ ). The correlation would increase if those most closely attached to the church maintained a high level of confessional voting while the less closely attached accen- 


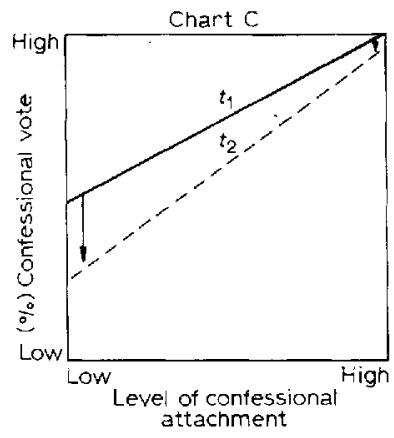

tuated their difference from the more attached by giving much less support to the party of the church.

Change initiated by those less attached to the church would, however, seem more likely to occur in the form of the second and quite different general type of change suggested at the beginning of this section. This would take the form of widespread loosening of ties to the church and a decrease in extent of confessional attachment. This would, of course, first produce a change in the distribution of confessional attachment, the consequence of deconfessionalization. The particular sequence envisioned might then find persons who already feel only a limited attachment to the church concluding that dissatisfactions with their confessional party are further cause for confessional estrangement and therefore reason for deserting both church and party at the same time.

If, however, the causes for dissatisfaction with party were not located primarily among marginal confessors but impinged equally across the entire continuum of confessional attachment, a third possibility for the locus of initial change would occur. The general level of confessional voting could drop along with a general decrease in attachment and the relational bond between confessional attachment and confessional voting need not be seriously altered. This would produce $t_{2}$ in Chart D.

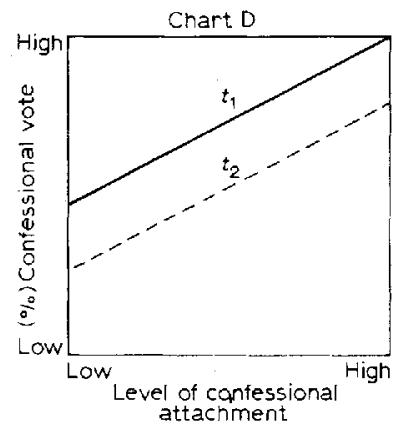


This third, quite different scenario, a scenario suggesting a change in level or distribution of confessional attachment that does not seriously alter the confessional attachment-confessional vote correlation, rests on a severe assumption. That assumption is that change, or likelihood of change, in confessional attachment is largely unrelated to the intensity of attachment. To put the problem in its negative form, if those most closely attached to a particular church have other distinctive social or personal attributes associated with resistance to change, it is commensurately less likely that their sense of attachment will be open to erosion and decay. Thinking for a moment about party identification, we know that strength or intensity of identification is strongly correlated with age and social status which are, in turn, indicators of generalized resistance to change. Consequently, strong identifiers are much less susceptible to change than are those weakly associated with a party. It follows that most of the change in level of party identification can be expected, and found, among those less intensely attached, such as the young. Comparable differences in attributes for high and low levels of confessional attachment would lead us to rule out any expectation that deconfessionalization would occur uniformly among those with high and low attachment alike and therefore would not alter the magnitude of other correlated differences such as those found in voting for confessional parties.

This highly speculative line of thought has been introduced to highlight the importance of knowing more about the correlates of confessional attachment and its relationship to confessional voting. The present discussion, and its successors more directly focused on the changes subsumed under the concept of depillarization, can lead to a fuller explication of the changes occurring in confessional voting only as we have a more complete understanding of the origin and dynamics of the changes being studied.

The work of Lijphart, Wolinetz and others has indicated sharp differences in confessional voting associated with regularity in church attendance. Our line of inquiry builds on this evidence and now extends it to permit a closer scrutiny of the political significance of confessional attachment.

\section{The Political Significance of Confessional Attachment}

The provincial elections of 1970 provide the basis for our first systematic view of the political correlates of confessional attachment. A joint examination of turnout, confessional voting and secular voting, 
TABLE V

1970 Vote by Confessional Attachment, for Persons with Homogeneous Religious Background

\begin{tabular}{|c|c|c|c|c|c|c|c|}
\hline \multirow[b]{2}{*}{ Voted } & \multicolumn{7}{|c|}{ Catholics } \\
\hline & Always & Usually & Sometimes & Seldom & Never & Non-religious & Total \\
\hline Confessional & $52 \%$ & $41 \%$ & $19 \%$ & $14 \%$ & $13 \%$ & $0 \%$ & $34 \%$ \\
\hline Other & 27 & 28 & 46 & 31 & 44 & 57 & 35 \\
\hline Non-Vote & 19 & 28 & 35 & 49 & 43 & 41 & 29 \\
\hline \multirow[t]{2}{*}{ Other } & 2 & 3 & 1 & 6 & 0 & 2 & 2 \\
\hline & 100 & 100 & 100 & 100 & 100 & 100 & 100 \\
\hline \multicolumn{8}{|l|}{ Number of } \\
\hline & \multicolumn{7}{|c|}{ Dutch Reformed } \\
\hline \multicolumn{8}{|l|}{ Voted } \\
\hline Confessional & $60 \%$ & $57 \%$ & $23 \%$ & $6 \%$ & $11 \%$ & $4 \%$ & $23 \%$ \\
\hline Other & 30 & 26 & 57 & 60 & 63 & 67 & 53 \\
\hline Non-Vote & 9 & 17 & 12 & 24 & 22 & 26 & 19 \\
\hline \multirow[t]{2}{*}{ Other } & 1 & $\begin{array}{l}0 \\
\end{array}$ & 8 & 10 & 4 & 3 & 5 \\
\hline & 100 & 100 & 100 & 100 & 100 & 100 & 100 \\
\hline \multirow[t]{2}{*}{$\begin{array}{l}\text { Number of } \\
\text { Cases }\end{array}$} & $(77)$ & $(47)$ & (61) & $(70)$ & $(90)$ & $(120)$ & $(465)$ \\
\hline \multirow{2}{*}{\multicolumn{8}{|c|}{ Voted }} \\
\hline & & & & & & & \\
\hline Confessional & $76 \%$ & $71 \%$ & $62 \%$ & & $10 \%$ & & $62 \%$ \\
\hline Other & 21 & 14 & 23 & & 67 & & 28 \\
\hline Non-Vote & 3 & 15 & 15 & & 23 & & 10 \\
\hline Other & $*$ & $*$ & 0 & & $*$ & & $*$ \\
\hline & 100 & 100 & 100 & & 100 & & 100 \\
\hline \multicolumn{7}{|l|}{ Number of } & (164) \\
\hline Cases & \multicolumn{7}{|c|}{ Non-religious } \\
\hline \multicolumn{8}{|l|}{ Voted } \\
\hline \multicolumn{7}{|l|}{ Confessional } & $2 \%$ \\
\hline \multirow{2}{*}{\multicolumn{7}{|c|}{ Other }} & 69 \\
\hline \multirow{2}{*}{\multicolumn{7}{|c|}{$\begin{array}{l}\text { Non-Vote } \\
\text { Other }\end{array}$}} & 23 \\
\hline & & & & & & & 6 \\
\hline & & & & & & & 100 \\
\hline \multicolumn{7}{|c|}{ Number of Respondents } & $(132)$ \\
\hline
\end{tabular}

* = no cases

$0=$ rounded off to zero

with data as displayed in Table $\mathrm{V}$, sharpens our understanding of confessional attachment in a number of domains. We may note first that confessional attachment as measured is a continuum with a systematic variation in voting behavior associated with variation in level of attach- 
ment. Within each of our three religious groups there is a steady decline in confessional voting as one moves from those most closely attached to the church to those least attached to the church of their childhood.

This relationship is complemented by two other correlations: the vote for the secular parties tends to increase with each decrease in confessional attachment, and the decision not to participate in the electoral voting also increases quite systematically and dramatically. Although less attention has been directed to the participatory implications of deconfessionalization, we now have striking evidence that nonvoting is at least a correlate of weak confessional attachment. Under the relatively new rules of the electoral game in The Netherlands, the contest is not a zero sum game of the confessional parties against the secular; the third option of not voting at all appears to increase in attractiveness as confessional attachment declines.

The information about nonvoting may also cast some light on the question of whether we are simply noting correlates of a static and continuing state of affairs concerning confessional attachment or whether we are also observing the consequences of real change and deconfessionalization. Perhaps the most provocative lead concerns nonvoting among the nonreligious. Nonvoting among the first generation nonreligious within the three confessional groups $(41 \%$ among former Catholics, 26\% among former Dutch Reformed and 34\% among former Calvinists) tends to be greater than nonvoting in the group composed of the second generation nonreligious (23\% nonvoting). The higher rate of nonvoting among the nonreligious with confessional backgrounds suggests rebellion or active rejection rather than long standing apathy toward a system traditionally based on church-related pillars of social organization and political expression.

Preliminary investigations suggest strong confirmation of this hypothesis. In response to a series of questions about electoral reform, the three newly deconfessionalized sets of electors gave much stronger support for electoral reform than did their former co-religionists, while at the same time the second generation nonreligious gave much less support to reform, matching the average for the total population on these questions just as they matched the national figure on nonvoting. Other indications of civic concern such as general interest in politics and interest in the provincial elections themselves, participation in political discussions, and use of the mass media to follow political affairs also run counter to the hypothesis that the recently deconfessionalized were simply reflecting lifelong disinterest in politics when they chose not to vote. Although much more study is needed, our tentative conclusion is that the absence of religious preference on their part is the direct result 
of recent rejection of prior religious identifications. If so, they may give us a better indication of the likely immediate consequences of further deconfessionalization for the nation's politics than do the second generation nonreligious.

The patterning of the 1970 vote among the three confessional parties brings us back to some of our earlier speculations. Although the Dutch Reformed are the weakest in confessional attachment and in confessional voting, the political meaning of variation in their confessional attachment seems every bit as clear for them as for the other two groups. The correlation between confessional attachment and confessional voting is, if anything, marginally higher for the Dutch Reformed than for the Catholics. In particular, those more closely attached to the church set a clear standard with 3 out of every 5 votes going to a Protestant confessional party while the KVP receives no more than 2 out of every 4 votes cast by Catholics with a comparable level of confessional attachment.

Although we shall not at this point attempt a systematic reconstruction of recent changes in the confessional vote, it should be noted that the decline of the Catholic vote for the KVP since 1956 doubtless has meant a reduction in the confessional attachment-confessional vote correlation (depillarization) as well as some loss through decreased attachment (deconfessionalization). Noting the sharp differences in the levels of confessional voting for Catholics against both the Dutch Reformed and Calvinists within the comparable top two categories of attachment, one may wonder whether the strength of the KVP might not continue to decline, after the model represented by Chart $B$, even without any significant decrease in confessional attachment or increase in deconfessionalization. Certainly among those professing the highest degree of religious identity the relevance of a confessional vote for confessional attachment is already much lower among Catholics than in either of the other two groups, and we will shortly note a similar pattern in the parliamentary elections of 1972 .

\section{The Social Correlates of Confessional Attachment}

With the relevance of confessional attachment for confessional voting now partially in view, attention can be given to the location of confessional attachments in the broader social structure. A number of expectations guide our inquiry. For example, we would expect increased age to be a correlate of closer confessional attachment. To the extent that the churches are conserving institutions, a part of the establishment of a 
TABLE VI

Age as a Correlate of Confessional Attachment, 1970

\begin{tabular}{|c|c|c|c|c|c|}
\hline \multirow[b]{3}{*}{ Often Attend* } & \multicolumn{5}{|c|}{ Catholics } \\
\hline & \multicolumn{4}{|l|}{ Young } & \multirow{2}{*}{$\frac{\text { Old }}{68 \%}$} \\
\hline & $51 \%$ & $52 \%$ & $61 \%$ & $71 \%$ & \\
\hline Attend Less Frequently** & $22 \%$ & 24 & 17 & 11 & 14 \\
\hline Do Not Attend & 11 & 9 & 8 & 8 & 7 \\
\hline No Religious Preference & 16 & 15 & 14 & 10 & 11 \\
\hline Number of Respondents & $\begin{array}{l}100 \\
(87)\end{array}$ & $\begin{array}{c}100 \\
(193)\end{array}$ & $\begin{array}{c}100 \\
(157)\end{array}$ & $\begin{array}{c}100 \\
(127)\end{array}$ & $\begin{array}{c}100 \\
(169)\end{array}$ \\
\hline & \multicolumn{5}{|c|}{ Dutch Reformed } \\
\hline Often Attend* & $31 \%$ & $25 \%$ & $23 \%$ & $30 \%$ & $26 \%$ \\
\hline Attend Less Frequently** & 25 & 30 & 27 & 32 & 25 \\
\hline Do Not Attend & 21 & 16 & 20 & 17 & 23 \\
\hline No Religious Preference & 23 & 29 & 30 & 21 & 26 \\
\hline Number of Respondents & $\begin{array}{l}100 \\
(39)\end{array}$ & $\begin{array}{l}100 \\
(90)\end{array}$ & $\begin{array}{l}100 \\
(73)\end{array}$ & $\begin{array}{c}\overline{100} \\
(114)\end{array}$ & $\begin{array}{c}100 \\
(149)\end{array}$ \\
\hline
\end{tabular}

* Always and Usually, combined

** Sometimes and Seldom, combined

society, we might also expect higher social status to be associated with greater confessional attachment. And with urbanization as the source and site of social change, we might expect strong confessional attachments to predominate in rural communities.

Our inquiry, first at the level of simple zero-order or bivariate relationships and later at the level of multivariate analysis, confirms some expectations but fails to support others. The correlation of confessional attachment and age is reasonably typical of the entire set of relationships explored. As Table VI discloses, older Catholics were, indeed, more likely to report close confessional attachments than were the younger. The age-related differences in confessional attachment among Catholics were not extreme, but they were matched by observed differences among Calvinists, where only $45 \%$ of the younger but $64 \%$ of the older Calvinists reported regular church attendance. Among the Dutch Reformed, however, our expectations were not met at all. Table VI shows absolutely no systematic variation in their confessional attachment associated with differences in age. ${ }^{5}$

In general, the prime indicators of social cleavages or individual differences, such as class and sex, bore expected but very subdued confirmation for our expectations. More positive confirmations were pro- 
Urbanization and Early Attendance at Confessional School as Correlates of Confessional Attachment, 1970

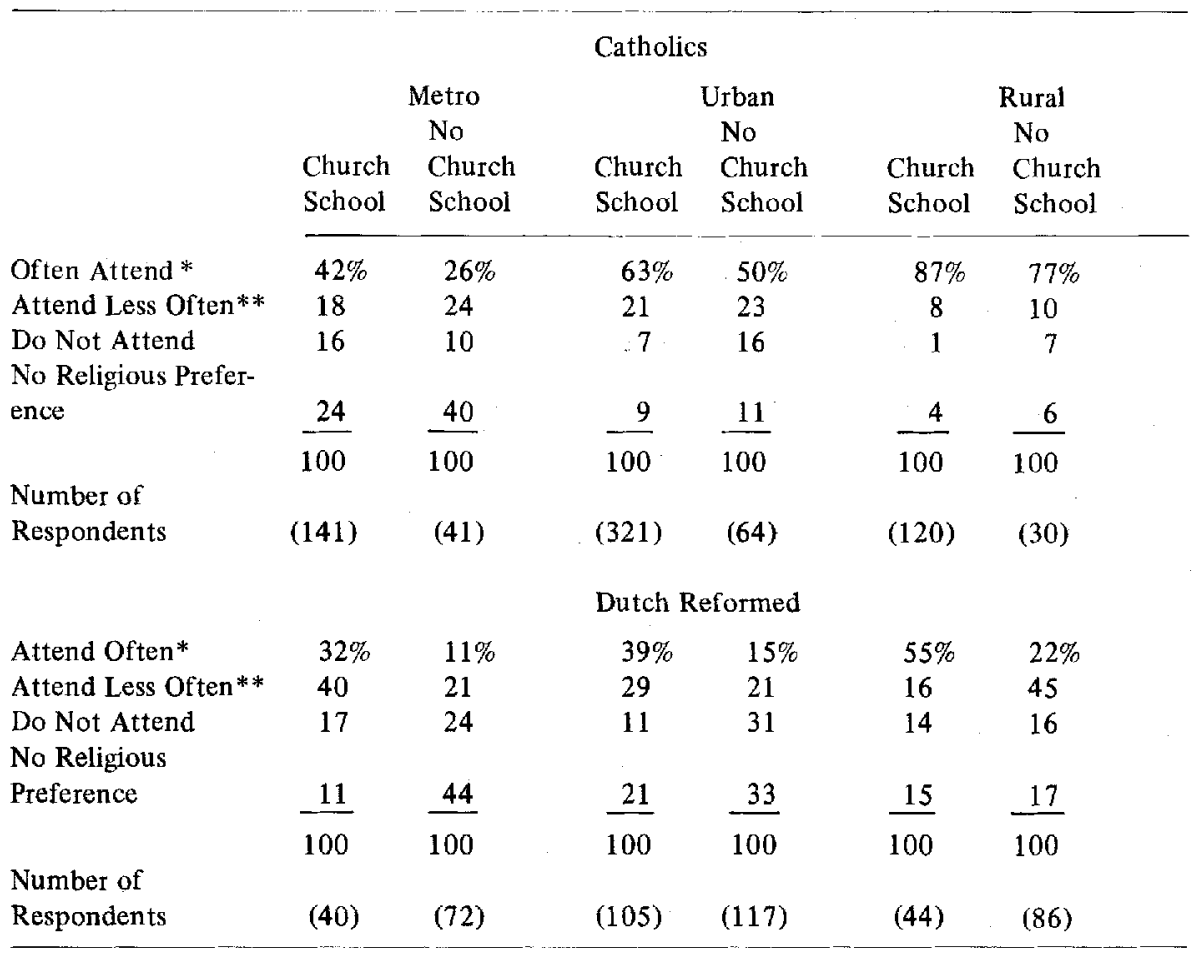

* Always and Usually

** Sometimes and Seldom

vided by the joint consideration of urbanization of place of residence and childhood attendance at confessional school. Table VII presents the data for Catholics and Dutch Reformed. ${ }^{6}$

Although attendance at confessional school was used to define our four analytic groups, and variance in current confessional attachment associated with early differences in school experience within the groups might be expected to be attenuated, church school attendance in childhood is nevertheless associated with stronger confessional attachment years later among adults, and particularly so for members of the Dutch Reformed community. Among residents of Amsterdam, Rotterdam and The Hague (the Metro dwellers in Table VII), early attendance at church school was a conserving, maintaining support for confessional attachment among Catholics as well, but its continued influence on Catholics residing in rural areas was very limited. The major source of 
the latter limitation, of course, is found in the close approximation to the J-curve of conforming behavior exhibited by all rural Catholics. Within both the Catholic and Dutch Reformed groups, the differences in attachment of extreme subsets (rural with confessional school and urban with no confessional school) are most impressive. Moreover, these differences - and the correlations they imply - persist despite simultaneous consideration of other social structural factors with which they are also correlated.

To test the correlations of urbanization and church school attendance against the possibility that their contribution to confessional attachment was only apparent, an artifact of their relationship with other aspects of social structure, a multivariate analysis with six additional factors was carried out. Except for the place of residence (urbanization) variable, none of the structural indicators to be examined were selected to identify the origins of deconfessionalization. Rather, they were chosen because our expectations were that the old, the women, the married, those who had attended church school, the less well educated or the occupants of positions of high status might be the sources of resistance to change; we had no expectation of achieving a better understanding of why the young, the men or the single might be impelled toward change. Only urbanization of residence was initially thought to reflect a possible source of change in confessional attachment.

The simultaneous inspection of independent effects was carried out with a multiple regression analysis of eight predictors of confessional attachment. Although most of the results, presented in Table VIII fit our first expectations, the degree of fit is surprising in its modesty. We must conclude that sex, age, subjective social class identification, occupational and marital status are at best only slightly correlated with the degree of confessional attachment. Across all three groups the magnitudes of the correlations (with two or three exceptions) are small indeed. In additive combination they provide a statistical accounting for only a minor part of the variance in confessional attachment. Where the political behavior correlates of confessional attachment were of a magnitude to encourage speculation about the consequences for a nation's politics, the social correlates tell us much less of substance about the social structuring of confessional attachment or about social constraints on deconfessionalization. Only the degree of urbanization of place of residence and the historical attendance at church school are strongly correlated with confessional attachment.

The absence of other strong correlates may be quite important to our theoretical understanding of the processes that are leading to deconfes- 


\section{TABLE VIII}

Multivariate Analysis of Social Correlates Of Confessional Attachment, 1970 (Entries are beta weights)

\section{Catholic Dutch Reformed Calvinist}

Sex: Male

Female

$0.05 * \quad 0.06$

0.05

Age: Old

$0.14 * *$

0.04

Young

0.05

Education: Low

0.02

High $0.05^{*} \quad 0.06$

Subjective Class: Low

\begin{tabular}{|c|c|c|}
\hline High & $0.09^{*}$ & 0.04 \\
\hline
\end{tabular}

Occupational Status: Low

\begin{tabular}{lll} 
Low & & \\
\hline 0.01 & 0.04 & 0.02
\end{tabular}

Married: Yes

No

$0.11^{* *} \quad 0.04$

0.08

No $0.11^{* *} \quad 0.04$

Attended Confessional School: Yes

$0.10^{* *}$

$0.27 * *$

$0.48^{* *}$

No

Urbanization: Metro

\begin{tabular}{|c|c|c|c|c|}
\hline Rural & & $0.36^{* *}$ & $0.17^{* *}$ & $0.22 * *$ \\
\hline & $\mathbf{R}$ & 0.41 & 0.35 & 0.56 \\
\hline espondents & & $(735)$ & $(465)$ & (164) \\
\hline
\end{tabular}

Number of Respondents

(735)

(465)

(164)

\footnotetext{
* Significant between $0.03-0.10$
}

** Significant at 0.02 or higher

All entries are presented as positively correlated with one or the other end of the continuum describing each independent variable or predictor.

sionalization. These data suggest the importance of one of the alternative views of the possible or likeiy incidence of change in confessional attachment discussed earlier. With these results before us, it is now much more possible to think of confessional attachment as a private, personal decision of conscience and social value that is not strongly influenced by social location or condition. Quite contrary to our understanding of partisan identification, strength of confessional attachment is neither bolstered nor threatened by the pervasive cleavages that impinge on so many other social or political decisions. There may indeed be, in general, great freedom of individual choice, with most of the 
usual attributes of social position that would restrain a decision to change, to deconfessionalize, quite limited in their effects. If so, confessional voting may swell or diminish without permanently altering the correlation between confessional attachment and the confessional vote because confessional attachment may be open to change among those whose attachments are strong as well as among those whose attachments are weak.

The one contemporary element in our analysis of confessional attachment that was found relevant to change in confessional attachment was the degree of urbanization of one's place of residence. One interpretation of the data leads to the hypothesis that confessional attachment, reflected in church attendance, might be influenced by local community norms. If this be true, then we should find changes in the degree of urbanization of one's residence associated with appropriate differences in the level of confessional attachment. Given the apparent rural norm of regular church attendance, persons who have moved from the city to the countryside should be more regular in their attendance than the city dwellers they left behind (and, inferentially, than they themselves had been when they were city dwellers). In the other direction, a residential move from the closeknit communities of the countryside to the anonymity of the Big City should be reflected in a much less regular pattern of attendance than exhibited by those remaining in the rural commune.

As with our assessment of change in confessional attachment, our measure of residential change is based on a comparison between only one earlier point in time and the present. Each person in our study was classified in terms of the urbanization of his or her place of residence during adolescence, between the ages of 10 and 16 . Using birth dates and census documents from past decades, Professor Rusk established the degree of urbanization of earlier residences in terms commensurate with current distinctions. A summary of the information about the stability and change in residential environment is presented in Table IXa. The two noteworthy facts in that table are: 1) there are no significant differences among the three confessional groups, and 2) with an expected preponderance of change favoring greater urbanization, there are enough instances of out-migration from the cities and urban centers to permit a relatively full test of our speculation.

Table IXb strongly supports our major hypothesis that confessional attachment changes as one changes residential communities and experiences new religious community norms for church attendance. First, it is evident that behavioral standards within each of the confessional groups vary sharply by degree of urbanization for those who live in residential 
TABLE IXa

Change in Urbanization of Residence, Childhood to Adulthood, for Major Religious Groups

\begin{tabular}{|c|c|c|c|}
\hline & Catholic & Dutch Reformed & Calvinist \\
\hline $\begin{array}{r}\text { Always Metro } \\
\text { Urban } \\
\text { Rural }\end{array}$ & $\begin{array}{l}15 \% \\
34 \\
16 \\
\end{array}$ & $\begin{array}{l}12 \% \\
28 \\
25 \\
\end{array}$ & $\begin{array}{l}11 \% \\
31 \\
24 \\
\end{array}$ \\
\hline $\begin{array}{l}\text { From Less Urban to More Urban } \\
\text { From Less Rural to More Rural }\end{array}$ & $\begin{array}{l}\quad 65 \% \\
23 \% \\
12 \\
\end{array}$ & $\begin{array}{l}65 \% \\
23 \% \\
12 \\
\end{array}$ & $\begin{array}{l}66 \% \\
20 \% \\
14 \\
\end{array}$ \\
\hline & $35 \%$ & $35 \%$ & $34 \%$ \\
\hline
\end{tabular}

TABLE IXb

Confessional Attachment as a Correlate of Change in Urbanization of Residence

\begin{tabular}{llrl}
\hline Always Metro & $-14^{*}$ & -59 & -28 \\
Urban & +41 & -13 & +44 \\
Rural & +87 & 1 & +84 \\
From Less Urban to More Urban & +45 & -14 & +64 \\
From Less Rural to More Rural & +41 & -30 & +52 \\
\hline
\end{tabular}

* Entry is a mean score for confessional attachment; it is the proportion of those who attend always or usually minus those who never attend or have no religious preference.

contexts similar to those in which they were reared. Catholics, in particular, present a very sharp contrast between the metropolian and rural settings, with the urban dwellers of medium sized cities falling rather neatly between the two extremes. Among the Dutch Reformed and the Calvinists, residents of the metropolitan centers are sharply different from the remainder, with the smaller differences between the urban and rural dwellers still consistent with our expectations.

Within all three groups, the specific locus of residential change is remarkably similar; most movement from less urbanized to more urbanized communities is in fact from rural to urban, and most movement from more urbanized to less urbanized places is from the metropolitan centers to smaller cities. These uniformities facilitate our interpretation of Table IXb. Catholics moving from smaller to larger places have a mean score on Confessional Attachment that is some 40 points lower than the rural score but almost identical with the "core" urban score. The Dutch Reformed moving to the urban areas show a score 15 points lower than that for rural residents but, as with the Catholics, their level almost exactly matches the level of core urban attachment. Calvinists 
show the least decline, 20 points (from +84 to +64 ) and those moving to the cities maintain a level of attachment that is clearly higher than the general level in their new environments although lower than that they left behind.

Movement away from the metropolitan and urban centers produces a nicely complementary picture. The confessional attachment score for Catholics who have left the metropolis is 55 points higher than for those who have stayed behind, and the movers are just as faithful as the long-time urban dweller. The magnitude of comparable differences is similar for the Dutch Reformed. Those who have moved to smaller places show an attachment score 29 points higher than the lifelong metropolitan dwellers, although their attachment lags behind that of their new neighbors among the constant urban residents. Calvinists who have moved out into less densely populated areas show a much larger degree of changed attachment than did their co-religionists who moved into the cities, and with the imputed changes again almost perfectly consonant with the hypothesized importance of local norms. In short, six of six comparisons are consistent with the hypothesis that confessional attachment is heavily influenced by established local group norms of behavior and will change as residential movement confronts a person with a new set of norms.

If the preceding analysis has led to correct inferences, social norms rather than nonreligious cleavage structures dominate stability and change in confessional attachment. Insofar as the norms of religious allegiance are tied to a sense of community or lack of community, residential mobility may be playing a major role in shaping the future of both church and church related politics. And if increasing urbanization continues to be the dominant pattern of population movement, a continued trend away from the churches and their confessional parties would seem likely to follow. ${ }^{7}$

\section{The Political Correlates of Confessional Attachment, 1972}

For a more complete examination of the political consequences of inferred deconfessionalization we turn to the parliamentary elections of 1972. The basic contours of the relationship between confessional attachment and electoral behavior are much the same in 1972 as they were in 1970 . However, there are some differences that may be largely a commentary on the difference between provincial and parliamentary elections and, as such, are not of concern in this discussion since we do not intend to document or explain differences between types of elec- 
TABLE X

1972 Vote by Religious Backgrounds for Four Major Groups

\begin{tabular}{lcccc}
\hline & K & DR & C & N-R \\
\hline Confessional* & $42 \%$ & $22 \%$ & $72 \%$ & $3 \%$ \\
Left* & 27 & 41 & 14 & 63 \\
Other* & 18 & 27 & 9 & 23 \\
NV & 11 & 7 & 4 & 10 \\
Ref, DK, NA & 2 & $\underline{3}$ & 1 & 1 \\
& 100 & 100 & 100 & 100 \\
Number of Respondents & $(550)$ & $(321)$ & $(123)$ & $(94)$ \\
\hline
\end{tabular}

* Only 14 out of 905 voters from homogeneous religious backgrounds crossed religious lines: 9 out of $490 \mathrm{~K}$ voted ARP or CHU

2 out of 303 DR voted KVP

3 out of 112 C voted KVP or CHU

Confessional parties again include KVP, ARP, CHU, SGP and GPV, as in Table IV. The left includes: PvdA, Partij van de Arbeid, CPN, Communistische Partij Nederland; PPR, Politieke Partij Radicalen; PSP, Pacifistisch Socialistische Partij, and D'66, Democraten '66. The "Other" category is a residual group ranging from the Center to the Right and includes the VVD, Volkspartij voor Vrijheid en Democratie; DS '70, Democratisch Socialisten '70; BP, Boeren Partij; NMP; and CDU.

tions. But to the extent this is so, the parliamentary elections seem a better - a more familiar and more thoroughly understood - base for an extension of this exploratory inquiry than the provincial elections.

A comparison of relevant data for the 1972 parliamentary elections (Table X with Table IV) indicates something of the pervasiveness of the political correlates of confessional attachment, as well as some of the sources of variation. Within each confessional group, roughly similar proportions supported their respective confessional political parties in both election years. In 1970, however, nonvoting was much higher than in 1972. Therefore, the aggregate differences between the two elections consist in part of a trade-off between nonvoting and voting for the nonconfessional parties. In the parliamentary election of 1972, as earlier, votes the confessional parties lost did not stray across confessional lines but went almost exclusively to secular parties, or into the abstention from voting.

Despite the increases in voter turnout in 1972 over 1970, the correlation between nonvoting and strength of confessional attachment is still evident as the parliamentary elections are compared to the provincial elections of two years earlier. The greater detail presented in Table XI (compared to Table $\mathrm{V}$ ) does, however, expose another, even stronger, association with confessional attachment: there is a strong negative 
TABLE XI

Confessional Attachment as a Correlate of the 1972 Vote for Parliament

\section{Catholics}

Always Usually Sometimes Seldom Never No Religious Total

Pref.

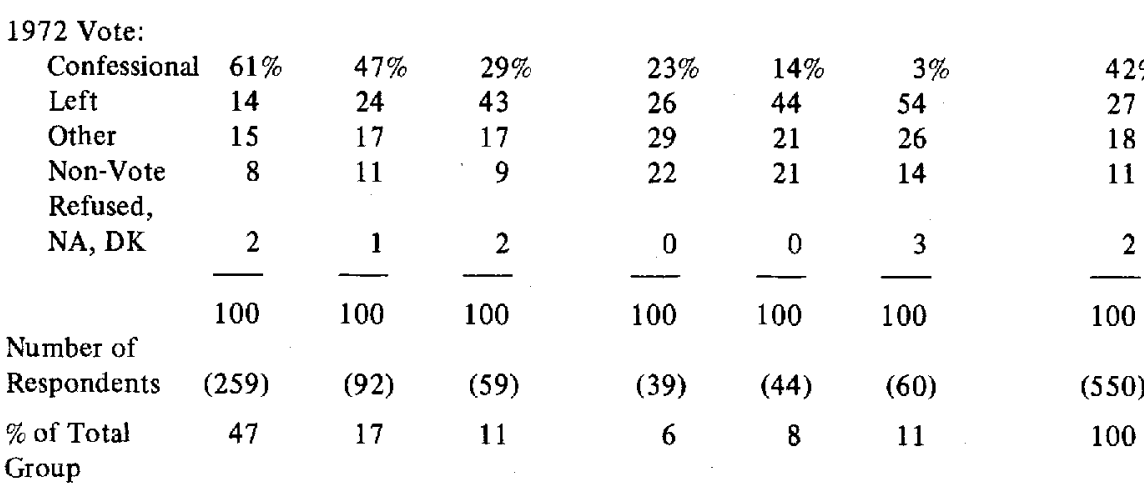

Dutch Reformed

Always Usually Sometimes Seldom Never No Religious Total Pref.

\begin{tabular}{|c|c|c|c|c|c|c|c|}
\hline \multirow{2}{*}{\multicolumn{8}{|c|}{1972 Vote: }} \\
\hline & & & & & & & \\
\hline Conressional & $65 \%$ & $50 \%$ & $16 \%$ & $18 \%$ & $3 \%$ & $4 \%$ & $22 \%$ \\
\hline Left & 8 & 26 & 25 & 39 & 68 & 57 & 41 \\
\hline Other & 19 & 18 & 49 & 32 & 19 & 23 & 27 \\
\hline Non-Vote & 4 & 0 & 5 & 7 & 8 & 13 & 7 \\
\hline Refused, & & & & & & & \\
\hline NA, DK & 4 & 6 & 5 & 4 & $\underline{2}$ & 3 & 3 \\
\hline & 100 & 100 & 100 & 100 & 100 & 100 & 100 \\
\hline $\begin{array}{l}\text { Number of } \\
\text { Respondents }\end{array}$ & $(48)$ & (34) & (43) & $(56)$ & $(60)$ & (79) & (321) \\
\hline$\%$ of Total & & & & & & & \\
\hline Group & 15 & 11 & 13 & 18 & 19 & 24 & 100 \\
\hline & Calvinist & & & & & & \\
\hline & Always & Usually & Infrequent & Never & No $\operatorname{Rel}$ & gious Pref. & Total \\
\hline 1972 Vote: & & & & באב & & - & \\
\hline Confessional & $88 \%$ & $75 \%$ & & $37 \%$ & & & $72 \%$ \\
\hline Left & 6 & 17 & & 28 & & & 14 \\
\hline Other & 6 & 4 & & 19 & & & 9 \\
\hline Non-Vote & 0 & 0 & & 16 & & & 4 \\
\hline $\begin{array}{l}\text { Refused, } \\
\text { NA, DK }\end{array}$ & 0 & 4 & & 0 & & & 1 \\
\hline & 100 & 100 & & 100 & & & 100 \\
\hline $\begin{array}{l}\text { Number of } \\
\text { Respondents }\end{array}$ & (67) & (24) & & (32) & & & (123) \\
\hline$\%$ of Total & & & & & & & \\
\hline Group & 58 & 20 & & 22 & & & 100 \\
\hline
\end{tabular}


correlation of confessional attachment with voting for parties of the left. The left does less well than the secular center and right among the minority of the closely attached who defect to vote outside their confessional party; but the immense nonconfessional vote of those with confessional origins who no longer attend church service or who deny a personal religious preference goes to parties of the left in ratios of better than 2 to 1 . There is a mild and somewhat irregular tendency for the secular non-left to gain votes as the level of confessional attachment decreases, but the striking regularity is the much larger and virtually monotonic increase in support for the parties, often new parties, of the left.

The most dramatic message conveyed by Table XI describes the extent to which voting for a confessional party is tied to the level of confessional attachment. The strength of the association is just as strong in the context of a national parliamentary election as it is in the provincial elections. If level of confessional attachment is, for the members of our three groups, a reflection of deconfessionalization, further movement toward deconfessionalization must indeed bode ill for the major confessional parties. And with the religious pillars playing a less and less central role in defining the dimensions of the Dutch party system (Daalder and Rusk, 1972), it becomes even more important to understand the specific political consequences of deconfessionalization.

The search for a more adequate understanding could, and ultimately must, follow a number of quite different courses. However, our present inquiry is limited to three aspects of the voting decision: the decision to vote or abstain, the decision to support one's confessional party or defect, and, for those who defect, the decision to vote for a party of the left or for some other secular party. Our line of inquiry is also limited to a concern with the basic indicators of location in the social structure. Questions of changing values attached to religious, political and other social behavior are reserved for future study. Similarly, we shall not explore those belief systems responsible for stability and change in political and religious behavior. On a more detailed level, we shall test neither the inferential connections between the static level of confessional attachment and the dynamic process of deconfessionalization nor the linkage between deconfessionalization and the subsequent depillarization that deprives church-centered social, economic or political institutions of their traditional support.

\section{THE DECISION TO VOTE}

In electoral research it has always been easier to account for partisan 
preferences of voters than to explain the decision to vote or abstain. The recent book by Verba and Nie (1972) on Participation in America performs an invaluable service in delineating the complexity of the processes involved in political participation and argues persuasively the role of each of the many factors that are relevant to a full understanding of the phenomenon. A maximum effort to account for turnout (voting and nonvoting) in the parliamentary elections of 1972 would take us well beyond the purpose of this paper. Consequently, we have largely limited our assessment of the role of confessional attachment in facilitating the decision to vote to an examination that takes into account the seven nonreligious factors considered in the earlier analysis of the social correlates of confessional attachment. However, two further measures of social attachment that may be relevant to social and political participation have been added. Given the history of the pillarization of social organization in the Netherlands, it seems appropriate to consider the possibility that membership of trade unions, professional organizations and other voluntary social groups could affect, and perhaps offset, the decline in church-related influences on political participation. Measures of such memberships have been added to our analysis of the 1972 election. Finally, attendance at church school was retained as an independent source of "explanation." Even though it is not necessarily a good measure of current social location, nor a good indicator of current exposure to socio-religious influences, it nonetheless may reflect aspects of pillarization and therefore is added to the measures of membership in our strategy for isolating the effects of confessional attachment.

Our analytic strategy is to examine the relationship of confessional attachment to voting turnout while simultaneously taking account of the contribution of the other ten variables to the same act of voting or not voting. This strategy permits a judgment about the magnitude of the direct relationship between confessional attachment and voting. It neither forecloses nor tests the possibility that confessional attachment is a mediating or intervening variable crucial to the act of voting but not directly or proximally influential. This latter possibility is best illustrated by the data pertaining to the Catholic group presented in Table XII. ${ }^{8}$ Despite a quite clear "zero order" correlation in the bivariate displays of nonvoting in Table XI, the correlation between confessional attachment and nonvoting of Catholics disappears when other factors related to Catholic turnout are taken into account. Age, sex, education and early attendance at a Catholic school are visible determinants of the level of confessional attachment (see Table VIII) and of turnout; but, formally speaking, confessional attachment itself appears to be a me- 
TABLE XII

Multivariate Analysis of Turnout (Vote/Non-Vote) in 1972 Parliamentary Elections

Catholic Dutch Reformed

Sex: Male

Female 0.01

0.06

Age: Old

$0.11^{* *}$

0.01

Young

Education: Low

High

$0.21 * *$

0.11 *

Subjective Social Class: Low

$0.14 * *$

High

0.09

Occupational Status: Low

0.08

High

0.07

Married: Yes

$0.22 * *$

No

0.06

Attended Church School: Yes

$0.12 * *$

No

0.05

Confessional Attachment: High

0.03

$0.13 *$

Low

Member of Trade Union or Professional

Organization: No Yes 0.07

0.02

Member of Other Voluntary Organization: No

0.02

Yes

0.01

Urbanization: Metro

\begin{tabular}{lcc}
\hline Rural & 0.07 & 0.04 \\
Percent Not Voting & 11 & 7 \\
$\mathrm{R}=$ & 0.28 & 0.31 \\
Number of Respondents & $(550)$ & $(321)$
\end{tabular}

* Significant between $0.03-0.10$

** Significant at 0.02 or higher

diating variable located somewhere in the causal sequence leading to the decision to vote or not vote, but not having any direct or independent bearing on that decision. For members of the Dutch Reformed group, however, the original simple relationship noted in Tables V and XI is not "explained away" by the introduction of other explanatory factors. 
Confessional attachment remains one of the elements clearly and directly associated with voting turnout - those closely attached to the church get out and vote, while the deconfessionalized tend not to vote.

The smallest of our four analytic groups, the second generation nonreligious, provides an interesting and potentially illuminating contrast with the Catholic and Dutch Reformed groups. Utilizing only the nine factors not explicitly related to ties with a church, it is possible to explain a much larger fraction of the variance in their turnout than the full set of eleven variables explains for the two religious groups examined in Table XII. The multiple correlation coefficient for the nine-variable prediction of turnout for the nonreligious is 0.47 ; the eleven-variable predictions for the religious groups were 0.28 and 0.31 .

An even sharper contrast appears as we tighten the logic of the comparison. First, to contrast religious with nonreligious populations, it is necessary to eliminate from the analysis of the religious groups the first generation nonreligious, the deconfessionalized members of the Catholic and Dutch Reformed groups who no longer profess any religious preference. Second, to insure comparability in the multivariate determination of turnout, it is necessary to eliminate confessional attachment and attendance at confessional school as predictors of turnout for those retained in each of the religious groups. As Table XIII indicates, these two constraints reduce the multiple correlation coefficients to 0.22 for both Catholics and Dutch Reformed. The personal attributes that tend to define social location and experience remain very weak predictors of turnout for persons of the Catholic or Dutch Reformed faiths. As noted, however, the same attributes are significantly and strongly correlated with the turnout of the second generation nonreligious.

The inquiry can be extended to embrace the two groups of first generation nonreligious (the "deconfessionalized" excluded in the transition from Table XII to Table XIII). The turnout of all three groups professing no religious preference (analyzed in Table XIV) is highly correlated with the selected personal attributes. The coefficients of multiple correlation are all more than twice as large for the nonreligious as for the religious. This striking difference in our ability to account for voting turnout of the religious and nonreligious clearly calls for further investigation. If the voting of the religious identifiers could have been accounted for at levels comparable to those obtaining for the nonreligious with the inclusion of confessional attachment (as in Table XII) one could hypothesize that the institutional supports associated with the church are simply being replaced by secular social supports (such as the organization memberships reflected in Table XIV) as deconfession- 
TABLE XIII

Multivariate Analysis of Turnout (Vote/Non-Vote) in 1972, for Persons with Religious Preferences, Using Non-Religious Predictors

Catholics Dutch Reformed

Sex: Male

Female 0.06

Age: Old

$0.10^{*}$

Young

0.08

Education: Low

0.02

High

$0.21 * *$

Class: Low $0.14 * *$

High

$0.17^{*}$

Occupation: Low

High $0.07^{*}$

Married: Yes

No 0.05

Urbanization: Metro

Rural

0.06

0.05

Member of Other Voluntary Organization: No

0.02

0.05

Yes

0.04

Member of Trade Union or

Professional Organization: No

Yes $0.06 \quad 0.02$

Percent Not Voting

$\mathbf{R}=$

Number of Respondents

(490)

* Significant between $0.03-0.10$

** Significant at 0.02 or higher

alization removes one from the direct influence of the church. However, a quite different situation seems to exist. Neither confessional attachment nor other group memberships give much evidence of direct support for political participation among those with a religious affiliation. Moreover, even the more familiar associations of sex, age, education and social class with voting or nonvoting are also virtually nonexistent for the religious groups. On the other hand, the social structural correlates of turnout among the nonreligious seem familiar and quite robust. Two of the strongest correlates, age and education, meet the 


\section{TABLE XIV}

Multivariate Analysis of Turnout (Vote/Non-Vote) in 1972 Parliamentary Elections, for Persons with No Religious Preference

$\begin{array}{lll}\begin{array}{l}\text { Second Generation } \\ \text { Non-Religious }\end{array} & \text { Former } & \text { Former } \\ & \text { Catholics } & \text { Dutch Reformed }\end{array}$

Sex: Male Female

$0.12-0.04$

Age: Old

$0.22 * *$

$0.42^{* *}$

0.03

Young

Education: Low

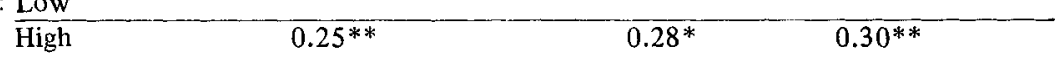

Subjective Social Class: Low

$0.07 \quad 0.11$

High $0.14^{*}$

Occupational Status: Low 0.07

Married: Yes

High 0.05

No

0.07

$0.22^{*}-0.48^{* *}$

Urbanization: Metro 0.06

Rural $0.37^{* *} \quad 0.08$

Member of Trade Union or

Professional Organization: No 0.09

Yes $0.31^{* *}-0.18^{*}$

Member of Voluntary (Informal)

Organization: No 0.02 0.03

Yes

Percent Not Voting

$\mathrm{R}=$

Number of Respondents

9
0.47

(94)

$(60)$

0.14

* Significant between $0.03-0.10$

** Significant at 0.02 or higher

almost universal expectations that the older rather than the younger, and the better educated not the less, will swell the ranks of the voting public disproportionately. But variability in turnout of persons with some religious identification is not predicted nor explained in the social structural terms common to the general explanations of vote turnout in the United States or the secularized nations of Western Europe. 


\section{SUPPORT FOR CONFESSIONAL PARTIES}

The manifest importance of confessional attachment to vote decisions is reasserted when we shift from a concern with understanding who votes to an interest in who among the voters support their confessional party at the polls. Moreover, where the multivariate analysis of turnout reduced the direct role of confessional attachment to one of limited direct explanatory power, comparable analyses of partisan preferences at the polls (presented in Table XV) appear to clarify and accentuate the place of confessional attachment as a direct factor in shaping voters' choices. Within all three confessional groups, confessional attachment is a prime determinant of support for the confessional party. Neither any structural attribute nor any combination of them exceeds the importance of confessional attachment in holding the religious confessors to the party of their church.

Beyond this most important central conclusion, the configuration of explanations of confessional voting contained in Table XV again challenges us to seek a fuller understanding of the similarities and differences among the major religious groups of the society. Among the Dutch Reformed, for example, we note that early attendance at confessional school is a significant element in the explanation of their contemporary behavior. The persistent role of church schooling through time is of interest. It is possible that relatively limited access to Dutch Reformed confessional schools when the present adult population was of school age meant that only the most devout and deeply religious families were likely to secure confessional school education for their children. From this it might follow that confessional school attendance is an indicator of a more thorough religious indoctrination and a deeper commitment for the Dutch Reformed than for the others. However, it may also reflect enduring social networks and church-centered influences that have persisted into adulthood and now sustain a religious commitment that is manifested both in higher participation in voting and in more faithful support of the confessional parties once at the polls.

\section{VOTING FOR THE LEFT}

The third and final stage of our inquiry into the political correlates of deconfessionalization centers on the third phenomenon noted in Tabel XI, the inverse correlation between strength of confessional attachment and the tendency to vote for parties of the ideological left. At 
TABLE XV

Multivariate Analysis of Voting Preference in 1972 Parliamentary Elections: Support for Own Confessional Party

\begin{tabular}{|c|c|c|c|}
\hline & $\begin{array}{l}\text { KVP } \\
\text { Catholic }\end{array}$ & $\begin{array}{l}\text { CHU + ARP } \\
\text { Dutch Reformed }\end{array}$ & $\begin{array}{l}\text { ARP } \\
\text { Calvinist }\end{array}$ \\
\hline Sex: Male & 0.02 & 0.03 & \\
\hline$\overline{\text { Female }}$ & & & 0.10 \\
\hline Age: Old & $0.07 *$ & 0.03 & $0.19 *$ \\
\hline \multicolumn{4}{|l|}{ Young } \\
\hline Education: Low & $0.12 *$ & 0.03 & 0.05 \\
\hline \multicolumn{4}{|l|}{ High } \\
\hline Subjective Social Class: Low & 0.01 & 0.01 & \\
\hline$\overline{\text { High }}$ & & & 0.03 \\
\hline Occupational Status: Low & & & 0.07 \\
\hline$\overline{\text { High }}$ & $0.18 * *$ & 0.06 & \\
\hline \multicolumn{4}{|l|}{ Married: Yes } \\
\hline$\overline{\text { No }}$ & 0.04 & 0.05 & 0.06 \\
\hline Attended Church School: $\underline{\text { Yes }}$ & & $0.22 * *$ & 0.09 \\
\hline$\overline{\text { No }}$ & 0.02 & & \\
\hline \multicolumn{4}{|l|}{ Confessional Attachment: Low } \\
\hline High & $0.40 * *$ & $0.39 * *$ & $0.15^{*}$ \\
\hline \multicolumn{4}{|l|}{$\begin{array}{l}\text { Member of Trade Union or } \\
\text { Professional Organization: No }\end{array}$} \\
\hline Yes & 0.02 & & 0.12 \\
\hline \multicolumn{4}{|l|}{ Member of Voluntary (Informal) } \\
\hline Organization: No & 0.01 & $0.11 *$ & 0.11 \\
\hline \multicolumn{4}{|l|}{ Yes } \\
\hline Urbanization: Metro & 0.06 & & \\
\hline$\overline{\text { Rural }}$ & & 0.01 & $0.27 * *$ \\
\hline Percent Confessional Voting & 48 & 25 & 73 \\
\hline$R=$ & 0.48 & 0.54 & 0.44 \\
\hline Number of Respondents & $(377)$ & $(242)$ & $(82)$ \\
\hline
\end{tabular}

* Significant between $0.03-0.10$

** Significant at 0.02 or higher

each stage in the analysis we are studying successively smaller subsets of the original groups. The nonvoters, with a disproportionate number of persons only weakly attached to their confessional groups, were set aside for the analysis of confessional voting. Now the confessional vot- 
ers, with a very disproportionate number of the faithful confessors, also have been set aside as we turn to those members of the religious groups who voted but not for their respective confessional parties. Despite these successive deletions of persons for whom confessional attachment

\section{TABLE XVI}

Multivariate Analysis of Voting for the Parties of the Left, 1972, Among Persons Who Did Not Support Their Confessional Parties

Catholics

Sex: Male Female

Age: Old Young

0.07

Dutch Reformed 0.02

Education; Low High 0.06 $0.16 * *$

Subjective Social Class: Low $0.35 * *$ $0.30 * *$

\section{High}

Occupational Status: Low

0.03 0.03

$$
\text { High }
$$

Married: Yes No 0.07

Attended Church School: Yes No

Confessional Attachment: High

Low $0.16 * * \quad 0.21 * *$

Member of Trade Union or

Professional Organization: No Yes 0.08 $0.14^{*}$

Member of Voluntary (Informal) Organization: No 0.01

Yes 0.08

Urbanization: Metro 0.05 0.07 Rural

Percent Confessional Voting

$\begin{array}{cc}48 & 25 \\ 0.44 & 0.54 \\ (259) & (244)\end{array}$

Number of Respondents

(259)

* Significant between $0.03-0.10$

** Significant at 0.02 or higher 
seemed to have one or another clear political consequence, the analysis of "left" voting presented in Table XVI clearly indicates a distinct third dimension on which confessional attachment plays a significant role. The parties of the left draw most heavily from the most deconfessionalized, and confessional attachments that were not sufficient to evoke support for the confessional party are nevertheless strong enough to restrain voting for the parties of the left in favor of support for the secular parties of the center and the right.

At the same time the influence of confessional attachment persists, the importance of other nonreligious factors is most striking when the focus shifts to vote choices among the secular parties. Moreover, in sharp contrast to explanations of turnout, a decision to favor the left when choosing among the secular parties has about the same correlates for the religious as for the deconfessionalized. This conclusion follows from an analysis dictated by the same logic that guided our analysis of turnout. Table XVII follows Table XVI (in parallel with Tables XII and XIII) with the elimination of the deconfessionalized from the religious groups and the deletion of the two church-centered variables from the roster of predictors. In contrast to the analysis of turnout, the prediction of multiple correlation drops only from 0.44 to 0.41 among Catholics and from 0.54 to 0.49 among Dutch Reformed.

The comparison of left voting among the religious in Table XVII with left voting among the nonreligious in Table XVIII suggests, moreover, that in sharp contrast to the implications of the analysis of turnout (Tables XIII and XIV), the social determinants of choice among secular parties are not greatly affected by one's religious background. It is true that occasional intergroup differences in the correlates of left voting can be found. The more general impression, however, is one of great similarity across the various groups.

The very high degree of success in explaining the vote of the second generation nonreligious suggests they may provide the norm against which to measure the assimilation of the deconfessionalized into the secular culture. At the same time, the comparability between the pattern of correlates associated with their behavior and those associated with professed Catholics and Dutch Reformed does not indicate that there are sharp cultural boundaries to be crossed. Once the option of voting for a confessional party is foreclosed, objective and subjective locations in the class structure combine in strong determination of the general orientation of a secular vote, whatever one's stance toward both religion and the church of one's childhood. 
TABLE XVII

Multivariate Analysis of Voting for Parties of the Left, 1972, Among Persons with Religious Preference Who Did Not Vote for their Confessional Party Using Only Non-Religious Predictors

\begin{tabular}{|c|c|c|}
\hline & Catholics & Dutch Reformed \\
\hline Sex: Male & & 0.05 \\
\hline Female & 0.07 & \\
\hline \multicolumn{3}{|l|}{ Age: Old } \\
\hline Young & 0.05 & 0.03 \\
\hline Education: Low & 0.05 & $0.25^{* *}$ \\
\hline \multicolumn{3}{|l|}{ High } \\
\hline Subjective Social Class: Low & $0.36 * *$ & $0.24 * *$ \\
\hline \multicolumn{3}{|l|}{ High } \\
\hline Occupational Status: Low & 0.03 & 0.07 \\
\hline \multicolumn{3}{|l|}{ High } \\
\hline Married: Yes & 0.06 & 0.00 \\
\hline \multicolumn{3}{|l|}{ No } \\
\hline Urbanization: Metro & 0.04 & 0.10 \\
\hline Rural & & \\
\hline Member of Voluntary Organization: No & & 0.07 \\
\hline$\overline{\text { Yes }}$ & 0.08 & \\
\hline \multicolumn{3}{|l|}{$\begin{array}{l}\text { Member of Trade Union or } \\
\text { Professional Organization: No }\end{array}$} \\
\hline$\overline{\text { Yes }}$ & 0.02 & $0.13^{*}$ \\
\hline Percent Voting Left & 60 & 60 \\
\hline$R=$ & 0.41 & 0.49 \\
\hline Number of Respondents & $(211)$ & $(177)$ \\
\hline
\end{tabular}

* Significant between $0.03-0.10$

** Significant at 0.02 or higher

\section{Conclusion}

The place of religion in Dutch politics has been undergoing a dramatic change. Public manifestations of the change have been recorded in a drop of almost $40 \%$ in the confessional vote since the end of World War II. There are many indications that this is part of a more general decline in the place of the church and religious faith in people's daily lives. The analysis presented in this paper has sought to outline the 
pation in the electoral process. Interest in politics and informal participation remain high, but the rejection of institutionalized religion is associated with what appears to be an active rejection of institutionalized politics. As the confessional parties continue to decline in strength and therefore in their ability to shape the policy alternatives and political options open to the voter, the level of abstention among the newly deconfessionalized may change. They may be drawn into voting and formal participation at a rate more congruent with their other expressions of concern with national politics. Although more work is needed in this domain, preliminary indications do not necessarily support the thesis that the trend is destined to produce an ever increasing number of alienated citizens who have rejected the church of their fathers and now refuse to vote.

However, for those who do remain in the active electorate, a continued decline in confessional attachment certainly forecasts a continued decline in confessional party vote. A reshaping of the Dutch party system may forestall a reduction in the number of citizens who vote, but unless there is a reversal in the movement toward deconfessionalization, the church-centered parties will certainly continue to lose support. More generally, each decreasing level of confessional attachment has associated with it a decreased likelihood of support for the party of the church. If these likelihoods remain constant, the vote for the church parties will only reflect changes in the distribution along the attachment continuum. Even with no change in the meaning of attachment (such as would occur if depillarization simply made the church - or religion - less and less relevant for politics), the confessional vote will rise and fall as there are changes in the level of confessional attachment.

Insofar as change in the future does involve general depillarization, or decreased political relevance of the church for all degrees of confessional attachment, the beneficiaries may be the parties of center and right as well as left. An across-the-board drop in level of confessional voting would mean many voters with strong confessional attachments would be turning to the secular parties and in doing so - if the recent past is any guide - would turn no more often to the left than to the other options open to them.However, insofar as the future brings a decline in confessional attachment without a decline in the relevance of confessional attachment for confessional voting, the parties of the left will benefit disproportionately as the newly deconfessionalized turn away from the parties of tradition and seek out the parties of change. 


\section{Notes}

1 Among a number of excellent analyses and discussions bearing on contemporary Dutch politics, the following will both provide a specific context for the subsequent analysis and a general context for locating Dutch politics in the larger ambit of Western European politics: Daalder (1966); Daalder and Rusk (1972); Lijphart (1968); Lijphart (1972); Lorwin (1971); Werkgroep Nationaal Verkiezingsonderzoek (1973); Wolinetz (1973).

2 The geographic distribution of confessional schools may be enough to limit the validity of this decision. It may well be that a dominant religious influence in childhood is not captured by our measures simply because no appropriate confessional school was nearby; if so, limited access to a religious education is now being interpreted as a background with minimal confessional commitment. However, if this is so, better measurement would only sharpen the observations to follow. See section on "The Social Correlates of Confessional Attachment."

3 Despite reference to the religious homogeneity of the groups, and the use of unitary labels for each, some groups are in fact composed of a number of different sects or denominations. "Dutch Reformed" is a shorthand reference to churches nominally categorized as Nederlands-Hervormd. This group embraces the so-called latitudinarian churches that are predominantly Calvinist in origin (including the Calvinistic Union or Gereformeerde Bond) but that are distinguished from the more fundamentalist religions which are, in turn, grouped under the heading of Calvinist or Gereformeerd. Where the Dutch Reformed label subsumes, among others, the Modernists, Medium-Orthodox and Walloon Church (Vrijzinnig, Midden-Orthodox and Waalse Kerk), the Calvinist group includes such churches as the Calvinistic (Gereformeerde Kerken), the Christian Calvinists (Christelijk Gereformeerd), the Old Calvinistic (Oud-Gereformeerd) and the Calvinistic Communities (Gereformeerde Gemeente).

4 Problems of assessing change are further exemplified by comparisons with other studies. A recent doctoral dissertation by Steven Wolinetz (1973) is most helpful here in presenting relevant data originally organized by Lijphart (1968) and Zeegers et al. (1967). A first useful comparison is with data presented by Wolinetz in Tables 4.8 and 4.9 of his dissertation manuscript. If this "Regular Attendance," defining "practicing" Catholics, is equated with "Usually or Always" attend church in our 1970 analysis, the proportion of "practicing" members among those with a Catholic preference has gone from $89 \%$ in 1956 to $75 \%$ in 1966 , down to $70 \%$ in 1970 ; comparable figures for the Dutch Reformed are $35 \%, 25 \%$ and $36 \%$; and $80 \%$ to $81 \%$ up to $86 \%$ for Calvinists over the same period. This suggests that only the Catholic pillar is declining in strength while the Calvinist pillar actually has increased. But the same data source used by Wolinetz reports that $11 \%$ of those raised as Catholics were no longer members of any church in 1966, whereas our data indicate only $13 \%$ in 1970 , a small decline indeed over the intervening four years; and the 1966 data report $7 \%$ of those raised as Calvinists are no longer church members while our 1970 data suggest $14 \%$ with no religion only four years later. To confuse matters further, the 1966 data show $32 \%$ of those raised as Dutch Reformed had left the church while our 1970 data show only $25 \%$ no longer identified among the faithful. In Table 10 of the Wolinetz manuscript, $35 \%$ of the population is described as of Catholic origin, $28 \%$ of Dutch Reformed origin and $14 \%$ Calvinist, against our 
estimates of $40 \%, 26 \%$ and $9 \%$. The Wolinetz definition finds $19 \%$ of the total population with a nonreligious background while our definition indicates no more than 7 or $8 \%$. Although each of the definitions may be well tailored to the goals of a particular analysis, it seems clear that they lack comparability with each other and provide very ambiguous assessments of recent changes in the size and strength of the religious pillars.

5 Here, and later, data for Calvinists will often be omitted from tables because the limited sample size produces unreliable and unstable results of intragroup analysis.

6 Appropriate bivariate relationships with urbanization hold also for the Calvinists, but such a large proportion of those in the Calvinist group reported attending a Protestant confessional school that our limited sample of Calvinists does not permit the three-way classification used in Table VII.

7 At the same time we note such apparent supporting evidence for our major hypothesis, we should also note two alternative interpretations. Although it seems likely that we have been observing the consequence of changes in confessional attachment for the six groups moving into or out of the city, we in fact have no direct evidence that attachment has changed. Those Catholics who moved from Amsterdam, Rotterdam or The Hague to small cities and the countryside may have taken a strong confessional attachment with them that "fit" their new circumstances without being influenced by those circumstances in the slightest degree. Second, even if real change in attachment has occurred for those changing residential contexts, the causal dynamics of movement and change could differ from those postulated in our major hypothesis. For example, the Dutch Reformed who moved into the cities may have done so to escape sanctions associated with breaking rural norms and to gain the anonymity and freedom of choice the city offers those who do not want to go to church every Sunday.

In the face of plausible alternative explanations, it still seems prudent to credit the evidence as suggesting that change in confessional attachment is associated with change in population size of place of residence. With so many aspects of Dutch society, from birth to death, organized around the church-related pillars it is hard to imagine that the network of social contacts, once reestablished, would not have a profound influence on personal attitudes toward the churches themselves. In The Netherlands, as much or more than anywhere in the industrialized west, we might expect the full gamut of social contacts in the office or factory, in the neighborhood, on the playing fields and in the clubs and social organizations to have a relevance for confessional attachment. And for persons who have left the familiar circumstances of the place where they grew up for new homes elsewhere, either the freedom or the lack of opportunity to set one's level of confessional attachment without regard for the familiar distinctions of age, sex, class or occupation provides new social definitions of the necessary or appropriate.

8 Problems of extreme multi-colinearity among crucial variables limit the utility of a comparable analysis of Calvinists. 


\section{References}

Campbell, A., Converse, P.E., Miller, W.E. and Stokes, D.E. (1960). The American Voter. New York: John Wiley.

Daalder, H. (1966). "The Netherlands: Opposition in a Segmented Society," in R.A. Dahl, ed., Political Oppositions in Western Democracies. New Haven: Yale University Press.

Daalder, H. and Rusk, J.G. (1972). "Perceptions of Party in the Dutch Parliament," in S.C. Patterson and J.C. Wahlke, eds., Comparative Legislative Behavior -. Frontiers of Interscience Research. New York: John Wiley.

Lijphart, A. (1968). The Politics of Accommodation: Pluralism and Democracy in the Netherlands. Berkeley: University of California.

Lijphart, A. (1974). "The Netherlands," in R.Rose, ed., Electoral Behavior: $A$ Comparative Handbook. New York: The Free Press.

Lorwin, V. (1971). "Segmented Pluralism, Ideological Cleavages and Political Cohesion in the Smaller European Democracies," Comparative Politics 3: pp. $141-175$.

Verba, S. and Nie, N. (1972). Participation in America: Political Democracy and Social Equality. New York: Harper and Row.

Werkgroep Nationaal Verkiezingsonderzoek (1973). De Nederlandse Kiezer 1972. Alphen aan den Rijn: Samsom Uitgeverij.

Wolinetz, S.B. (1973). Party Re-alignment in the Netherlands. New Haven: Yale University, dissertation.

Zeegers, L.H.L., Dekker, G. and Peeters, J.W.M. (1967). God in Nederland. Amsterdam: Van Ditmar. 